An ESRC Research Group

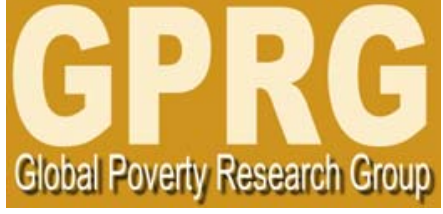

\title{
Pluralist Methodology for Development Economics: The Example of Moral Economy of Indian Labour Markets
}

\section{GPRG-WPS-053}

\author{
Wendy Olsen
}

\section{Global Poverty Research Group}

Website: http://www.gprg.org/

The support of the Economic and Social Research Council (ESRC) is gratefully acknowledged. The work was part of the programme of the ESRC Global Poverty Research Group. 


\section{Pluralist Methodology for Development Economics: The Example of Moral Economy of Indian Labour Markets}

by Wendy Olsen

Address for correspondence:

Institute for Development Policy and Management

Room 7.16 Harold Hankins Building

University of Manchester

Manchester M13 9PL

UK

Phone 0161-275-3043 or fax 0161-275-4722

Email wendy.olsen@manchester.ac.uk

Note: The support of the Economic and Social Research Council (UK) is gratefully acknowledged. The work was part of the programme of the ESRC Global Poverty Research Group.

\section{JEL Keywords}

B5, O17, O12, O53

๑) Wendy Olsen November 2006

This paper is forthcoming in the Journal of Economic Methodology, 2007. 


\title{
Pluralist Methodology for Development Economics: The Example of Moral Economy of Indian Labour Markets
}

\begin{abstract}
:
This paper adds a moral angle to a pluralist approach to development economics. Normative assumptions can be found in all the five main schools of thought that have analysed India's rural labour markets (neoclassical, new institutionalist, Marxist political economy, formalised political economy, and feminist). The theorisations that are used by each have normative overtones. I define overtones and distinguish them from normative undertones (i.e. elements of meaning that have an affect component). Statistical regressions in this literature are used to illustrate the types of undertones that are present. The undertones tend to cause performative contradictions for authors who claim value neutrality.

The various moral reasoning strategies available for meta-normative economic research do not offer easy solutions. However they convincingly support the case for mixed-methods research in development economics. Further research on normative overtones can be conducted using bridging discourses and interdisciplinarity that recognises the underlying social reality.
\end{abstract}

Keywords: pluralism, schools of thought, poverty, moral economy, mixed methods research, normative social theory.

\begin{abstract}
"As soon as language is employed in order to refer to ontology, the possibilities open up for different forms of categorization. Effectively, then, different schools of thought can be identified with different categorizations and conceptualizations of either an open-system, or a closed-system, ontology. . . The pluralism represented by schools of thought is structured." (Dow, 2004: 285)
\end{abstract}

\section{Introduction}

In this paper the Indian case is used to illustrate how development economics can be normatively rich while also being pluralist.

Most development economics assumes that positive economics can be separated from the 'ought' statements of normative claims (Lipsey, 1979, ch. 1). I have argued instead that the fact-value separation argument is false (Olsen, 2004; Olsen and Morgan, 2005) and that any important explanatory claim is likely to be closely or weakly connected to interesting normative claims. The present paper develops some new aspects of this argument. In development economics, a strong focus on competing explanatory frameworks has arisen, with a discussion of paradigms (Hunt, 1989) and of competing deductive frameworks being taken for granted in the subdiscipline (Mukherjee, et al., 1998: 3-26). In Mukherjee et al. (1998) and the seminal text by Todaro (1997), as elsewhere in orthodox economics, normative statements are seen as outside the standard remit of both neoclassical and new institutionalist 
economics. Instead the descriptions offered by economists are considered to be factual. Most economics authors consider normative statements to be a specialism of some other discipline such as social policy. This position is rather outdated since it rests upon epistemological assumptions that have been rejected by philosophers of science. Hands (2001), for instance, in his wide-ranging overview of economic methodology gives very little space to normative issues.

Indeed as Hands surveys the field, normativity is perceived mainly as having values about the choice of theory. But in this paper a realist position is taken about values in themselves by asserting that they attempt to reflect real goodness and not just subjective beliefs (Sayer, 2000: 58; 166; 174). One has values about the real world. The realist position on values has been explored in various publications outside economics (Cater and New, eds., 02004; New, 1996) but less so within economics. It is not simply a moral realism (which is discussed by Roth, 1987, and Olsen, 2006a) ${ }^{i}$ but rather a careful integration of lay values, researchers' evaluations, evidence, and reality that I am advocating.

The position taken here would fit into the economic methodology debates as a postfalsification and post-positivist approach. The old positivist notion that facts can be constructed to describe society quite independently of the observer's values has been fundamentally undermined, as Hands explains.i During the gradual decline of positivism, Quine, too, generated images of falsification that showed severe problems with the notion of testing hypotheses (Quine, 1953). Quine's model of knowledge is one in which the knower is located within the 'cube' of what is there to be known about. Thus Quine, like myself, is a reflexive scholar. Hands, too, describes numerous feminist reflexive scholars, but Quine's image of the situated knower actually predates them (Walby, 2001). Quine argued that the social and discursive grounding of statements in a particular locale or theory flavoured the falsification tests. It is widely accepted now that the Duhem-Quine thesis reveals difficulties with falsification. Specifically, as Hands argues, one can attempt to read Popper in terms of his critical rationalism without necessarily accepting that Popper's version of falsificationism leads to truth (ibid: pp. 298-302). iii A nice metaphor used by Hands to summarise the post-positivist viewpoint is that of a boat floating on an ocean; we are both in the boat and describing the boat. ${ }^{\text {iv }}$

The paper thus develops and promotes theoretical pluralism in which causal explanations that arise in competing or complementary schools, across a range of disciplines, are considered to be potentially relevant and worth considering (as indicated by the quote from Dow above). In other words competing explanations are brought to bear upon the specific problem, and to some extent these explanatory arguments are found to be complementary rather than incommensurate. Theoretical pluralism is controversial because it may set up competing theories as neighbours even while they have incommensurate assumptions. For the first time, in this paper, I offer a discussion of their competing grounding norms (which are surprisingly evident) and their ethical overtones. O'Neill, working on the same topic, argues the neoclassical economists tend to be subjectivist in their orientation, whereas the alternative is a substantive welfarist approach (O'Neill, 1998: 33). I work from the premise that theoretical explanations for Indian labour market outcomes are not value-neutral because there is a substantial 'good' outcomes that are sought by those who are trying to understand and study those markets. The improvement in 
welfare that is sought - by the researcher - must cause the ontological assumptions to be changed to allow for the objective goodness of well-being (or welfare) to be considered as a possibility. Instead of the subjectivist set of assumptions found in utility theory, a different 'realist' set of assumptions are being asserted here. This background has been developed by other authors, who are summarised by Hands (2001: 39; ch. 7), but I will offer some comparisons with standard neoclassical theory as we go along.

In particular, this paper offers an innovative and precise delineation of what the overtones and undertones of a theory are like. I give examples of norms that are being hinted at or explicitly referred to, and I illustrate that bridging between theories is highly relevant to development economists. Both overtones and undertones are variants of the commonsense notion of 'connotations'. The overtones of a theory are its overall normative orientations, which I call complex moral reasoning strategies. The undertones are the micro nuances of the language and phrasing used in a theory or in an empirical enquiry. Discourses used in research convey socially constructed notions of good and bad as well as other normative valuations. Implicit evaluative meanings are undertones which are carried through even though there would not always be unanimity about what exactly the connotations are.

There would be overtones and undertones in statistical research in particular. The constructivists would stress that the phrasing of questions in a survey implies particular social constructions of the things referred to. A realist ontology, on the other hand, would suggest furthermore that statistical research creates "ficts" (or "traces") that can reveal details of deep structures or of institutions (Olsen and Morgan, 2005; Danermark 2001). A realist ontology is by definition a depth ontology (Layder, 1998; Lawson, 1997). By this we mean that several structures interpenetrate each other in a layered, permeable, open system. ${ }^{\vee}$ Critical realism links weak constructivism with this depth realism. Qualitative conceptual frameworks lie underneath survey research because survey questions are framed in language. A strong fact-value distinction is therefore not considered tenable for any important sort of claim. Instead one makes warranted claims about reality which invoke values implicitly even if that is not one's core intention.

The idea of overtones and undertones represents just one particular aspect of the moral sentiments research that A. Sayer has been recommending (2005). Sayer argues that the norms held by particular respondents in research are very important. In this paper, however, I focus on the norms held by scientists who conduct and write up research. Issues of meaning and language have recently become central to the research methodology decisions made by labour economists. These are not merely technical issues but also require moral and ethical decisions.

Note that a 'moral' standpoint is a rather general approach to values and to what is considered good in human society. Ethics, on the other hand, usually refers to the difficult decision-making processes that occur in more contextualised specific situations. Wolfe, writing on ethics, has shown that American people in the $20^{\text {th }}$ century had complex ethical stances which linked up only partially, occasionally and flexibly with their stated moral stance. Macintyre (1990), writing about the differences between western science in the $20^{\text {th }}$ century vs. previous centuries, argues that ethics in the $20^{\text {th }}$ century involved more people in more contestation than in any 
previous century (ibid. and Maclntyre, 1985). The role of an academic, he argues, is not just to be an encyclopaedic expert or a parrot of tradition (Maclntyre, 1990). Instead it is to serve as a means to enhance public discussion of ethical issues that are intrinsically difficult. The paper is meant to be a further development of this argument.

\section{Five Schools of Thought}

To begin my study, I provide in Table 1 a summary of five important schools of thought on labour relations with particular reference to India. ${ }^{\mathrm{vi}}$ My review of the literature under the auspices of a Global Poverty Research Group project included studying the Indian Journal of Labour Economics, monographs such as Ramachandran (1990) and Harriss-White (2003), overviews such as Joseph (1995), Visaria and Besant (1994), and Papola and Sharma, eds. (1999), and annotated bibliographies such as Ramani Rao (1994). The resulting selection of five main schools of thought necessarily omits some existing scholars' work but does cover a huge range of theories. vii Dow (2004) has argued that schools of thought in social science necessarily overlap because they make reference to the same underlying society. She also argues that instead of being thought of as incommensurable (hence paradigmatically different), neoclassical economics and other less monist forms of economics can be compared and contrasted to good effect. Thus in Table 1 the neoclassical school is compared with new institutionalist, Marxist, feminist, and formalist economics. The five schools can be abbreviated NeoClassical Economics (NCE), New Institutionalist Economics (NIE), Marxist Political Economy (MPE), Formalist Political Economy (FPE), and Feminist Economics (FE); Olsen, 2006a) and they may already be familiar to readers.

Most development economists need to know how to combine schools, and all economists must decide which ones to ignore or discard. This paper describes

certain aspects of the normative content of these theories. By noting both explicit and implicit normative content, I am proposing new criteria (besides, for example, the traditional criteria of external validity and not being falsified) for choosing which theories to use.

\section{Normative Overtones as Complex Moral Reasoning}

Table 2 lists the normative reasoning modes that authors in each school usually invoke (row 1). These reasoning modes can be explicit or can be left implicit, because the traditions of each school often imply certain patterns of reasoning (such as Pareto Optimality) which provide normative reasoning for both the author and for their reader, even without it being explicit. The normative 'overtones' help provide a focus for an explicit discussion of the role that normative positions and discourseembedded norms play in economic explanations. However in addition, as shown in Row 3, there are also normative undertones.

All the theories have normative undertones because of the way that norms are inscribed within discourses as units of meaning that are put across whether or not the author intends to convey them. In other words, a development economist will often have normative undertones even if (and when) they attempt to avoid normative overtones. 
I will now describe more fully the distinction between normative overtones and undertones. Then in section 4 , undertones are described in more detail.

A normative overtone can be defined as a reasoning strategy that refers to either processual norms or to the moral judgements about outcomes, or both. Normative overtones make reference to an actual situation as well as to a possible or real comparable situation. The normative overtones thus compare what could be with what is, or compare two situations and judge one better (e.g. one is more efficient than the other). The analysis of normative overtones makes explicit the moral reasoning strategies that are being used by economic authors. Philosophers and heterodox economists have already noted various sorts of normative overtones in general terms (as reviewed by Dowd, 2002). Among philosophers, O' Neill for example has shown that different schools of economics have a different approach to the importance of civil society (1998). My use of the word 'overtone' refers to normative claims about how society could be made better.

Normative claims like these can be either implicit or explicit, or a mixture. Indeed it is normal to mask the over-arching claim during some stage of research (most obviously seen in the formalist method) in order that a variety of causal factors can be allowed for. Masking occurs in part by converting a matter of concern (e.g. inefficiency) to a matter of measuring certain quantities along metrics that are either objectively measurable or subjectively knowable (or both). The objectively measurable metrics include income, costs, profits, productivity, etc. The subjectively knowable quantities that are very important in orthodox economics include utility, profitability, and risk. If these conversions from matters of concern to matters of measurement were not carried out, simplistic causal statements might seem to be offering facile solutions to social problems.

Because of the lack of measurement within orthodox NCE models that use utility maximisation, bargaining, and indifference curves, there is usually an econometric step in orthodox research in which some kind of matching of concepts to measurable quantities is proposed. These matchings tend to be deductive in that they assume the theory correctly maps onto reality. There is an awareness of fallibility in proposing the correspondence of subjective concepts to measurable variates. A recent set of papers published in India noted that empirical development economics usually follows this pattern, Mookherjee, 2005.

Williams (2005) has noted that the notion of 'value' in this, and all, social theories takes on meanings at several levels ranging from micro to macro. He argues that the normative overtones refer to relative valuations of different states of affairs. For instance, an economy with high levels of waste and inefficiency is widely considered inferior to one with high efficiency (ceteris paribus). This kind of overview judgement is a normative overtone. Williams notes, however, that there are also valuations of particular measurable things, so that the very metric upon which measurement takes place - an income scale with currency units; a Likert scale with preference units, and so on - it itself a matter of normative interest. In the latter case, the theorist asserts that the measurable thing is going to be of wide interest and has an implicit scale of relative valuation. This type of normative valuation I will be calling a normative undertone because it neither requires nor necessarily implies an overall evaluation of 
states of affairs. viii In Williams' scheme, the undertones can be present but not measured. Another possibility is that those with are suited to measurement get measured, but some valued 'things' are not suited to cardinal measurement. He argues that it is not necessary for things to be measurable. They can still be present in reality (and reflected in the social meanings of language) even if they are not cardinally measurable. Thus, we can expand Williams' argument slights to note that ordinal and multinomial variables may imply a variety of normative undertones. Thus cardinal measurement - such as classical scales, principal component analysis, or income scales - is not the only way that economic concepts carry undertones of value.

In previous research I uncovered several types of moral reasoning strategy which would qualify as normative 'overtones' as described here (Olsen, 2005). Five strategies correspond roughly to the five schools of thought in Table 1. In Table 2 a summary is given.

Neoliberal and neoclassical economists have often made an explicit valuation that the freedoms provided by a market economy are preferable to the strong regulation and planning found in state-ist economies (Cammack 2002; Hunt 1989; and for a summary of the logic of NCE's moral reasoning with reference to rural farming production decisions, see Ellis, 1993). This substantive assumption that market coordination is really better than non-market coordination can be relaxed. Indeed it was most strongly found in liberal writings 1850-1914 that precede the neoliberal phase (this shift is traced by Dowd, 2000: ch. 2; Chang, 2003a). In neoclassical writings today, and in NIE, one often finds a weaker normative overtone. This is the ethical principle of Pareto optimality. Pareto optimality offers a capacity to compare any two states of affairs. If in the first state of affairs no one would judge themselves worse off than in the second state of affairs, and someone feels better off, then the first state of affairs can be unassailably judged Pareto optimal compared with the second. This particular kind of ethical judgement is not one made by the author, but by the actors themselves. Thus, the author can pretend to hold to a particularly weak value-neutrality whilst providing conditional statements that if $A, B$, and $C$ hold then state of affairs 1 will (or would) be Pareto preferable to state of affairs 2 . In this particular sense of a conditional and apparently factual statement, NCE and NIE economists play with counterfactuals and comparatives just as the proponents of other moral reasoning strategies do.

The Pareto optimality approach is often used to judge market economy preferable to an imperfect, uncompetitive, state-controlled or subsidised partially-market economy (one example is Hoff and Stiglitz, 1998). The question of market imperfections (vs. the model of perfect competition) offers a thin basis for recommendations. The author usually avoids making policy prescriptions about the real world in which the assumptions $A, B$ and $C$ do not necessarily hold true. However, in general, the claim is nevertheless present in the discourse that where markets are imperfect, improvements can be obtained by moving toward more public information, toward a more efficient allocation of resources, and/or toward regulation that helps avoid free riders and moral hazard. For an analysis of discourses of development and how neoliberal values of market-based freedom pervade some discourses, see Grillo and Stirrat (1996). Obviously the role of the state is controversial here, and this is often left to one side in the monistic (single-discipline) approach taken by economists who 
claim that politics is not part of their disciplinary expertise. ${ }^{\text {ix }}$ In summary, both NCE and NIE tend to use a Pareto Optimality framework for both implied and explicit normative overtones in their research.

Turning to MPE, the marxist concern with oppressive structures is often associated with an approach favouring the compression of incomes. Either land redistribution, or income redistribution through taxes, is thought to be able to cause a structural change which would reduce the ills of exploitation and oppression that arise from class power (e.g. Epstein, 1998). The strongly normative nature of such proposals is evident. One marxist author has also expressed criticisms of a variety of associative practices that strengthen the capacity of the powerful classes to control resources (Harriss-White, 2003: 199; 260-262). By noting that currently business-related civil society contributes to the reinforcement of inequality, Harriss-White indirectly asserts that there is a need for a (counterfactual) type of civil society that increases equality. By pursuing such counterfactual possibilities, seeking real referents to cases in which equality has been reached via civil society movements, Marxists could be tracing the complex reasoning that Sayer has advocated as part of moral economy. Sayer suggests that counterfactuals are important for moral reasoning (2000a). These counterfactuals can refer to comparative real referents or to real possibilities that have not occurred (a point picked up by other realist authors, such as Flyvberg (2001), in arguing that a useful social science will actually highlight aspects of possible futures and not only refer to society's actual past; Patomaki, 2006). In the Marxist reasoning, counterfactuals are nearly always present as the possible future structural changes are thought to influence what is considered to be possible and desirable modes of agency in the present.

Formalised political economy takes an interest in inter-agent power and hints that power is problematic, but it does not offer or use strong moral reasoning of the particular kind found in MPE. Formalised political economy, based heavily on mathematical models that use concepts arising from stylised facts about numerous societies, often hints at proposals for change that are likely to be consequentially good in a variety of contexts -- but only if a series of assumptions are also met. The assumptions made in these models, it would seem, must be met for their conditional claims to also be true. Since some assumptions of mathematical modelling are manifestly inaccurate ${ }^{x}$, it is not surprising to find the authors rather agnostic about particular policy areas. Instead, particularly in Basu's writing, problematic social issues such as child labour or usury have been decomposed into a model of the dynamic interaction of differentiated actors. No facile solutions are offered by Basu to the problem, because he is highly aware of the complexity of the interpenetrating structures and habituated behaviours that underlie the interactions that are being modelled (Basu, 2005; Basu and Van, 1998 and 1999; Basu and Tzannatos, 2003). For instance, in referring to child labour, Basu notes through a model of regulation that the effect of a small fine on firms who employ child labour may actually increase the incidence of child labour (Basu and Chau, 2003). Basu's focus has been on explaining the inner workings, the bargaining, and/or the dynamic triadic interplay of personal motives within a stylised scenario. In this way Basu avoids both local context (e.g. state policy matters) and the details of regional or cultural differentiation. This reasoning strategy is far from the impulse to reduce inequality that is commonly found among marxists. 
Among feminists, a number of strong policy recommendations have been made. These have taken two main forms: disapproval of oppressive social practices such as women doing work only inside the home (Beneria, 1979; Chakravarty, 1993; Dube, 1988); and encouragement of progressive or transformative practices such as women's groups taking action to promote the empowerment of women (Vohra, 1990; Mayoux, 1993; Bhowmik and Jhabwala, 1996). ${ }^{\mathrm{xi}}$ A debate about giving women access to rented or owned land has taken place between a Marxist feminist and another feminist (Agarwal, 2003a and 2003b; and Jackson, 2003). This debate presumes that the moral overtones of feminist economics are very suitable to a public policy debate.

In summary, none of the five schools avoids using normative overtones completely. However in some these are explicit moral reasoning strategies while in others they are either implicit or hidden. The pareto optimality criterion is a particularly interesting approach in which subjective valuations are considered to be socially separate from the valuations of the development economist her/himself. Thus an attempt at value neutrality is made by some NIE and NCE writers even while normative issues, such as comparing counterfactuals with real situations, are being taken up in detail. It is as if some authors need to feel socially distanced from a scene in order to feel that they can viably or fairly assess how good or bad certain changes in that scene would be. In MPE and in feminist economics, however, neutrality is considered impossible (for reasons to do with the inevitable involvements of the economist; see Flyvberg, 2001).

Clearly a huge agenda opens up when we consider how well qualified academic researchers are to make specific proposals for change. In recent years the human capabilities agenda has begun to widen this scene of discussions of transformation (Nussbaum, 1993, 1999). Human capabilities theory may be a useful way forward for self-conscious approaches to social transformation. However, in this paper I want to focus on the impossibility of non-normative economic explanations of labour market outcomes. Thus I keep away from this wide moral agenda and instead, returning to Table 2, now turn to the normative undertones found in economic analysts' discourse.

\section{Moral Undertones are Ever-Present}

The term 'moral undertone' aims to highlight the implicit and sometimes unintended nuances that have meaning within particular discourses. These meanings - and especially their affect component - are not necessarily part of the intended reasoning strategy of the economic researcher. I refer to discourse to mean the socially shaped regularities of how communicative acts occur (not just referring to texts themselves). ${ }^{\text {xii }}$ A discourse includes implicit rules and assumptions, which are often bent or broken but which act to normalise speakers' acts and to make them comprehensible to others (Fairclough, 2003). A discourse has among its components the words used to refer to agents; the assumptions about appropriate body language or style in each genre (such as advertising, political leaflets, economic explanations, or public speeches); and socially embedded ${ }^{\mathrm{xii}}$ meanings of particular words, phrases and gestures. Among the embedded meanings which are carried by speech acts are the normative undertones of approval/disapproval, the assumed aims of action (e.g. profit-making in business discourse), and a wide range of other 
meanings that proficient people can read into others' communicative acts. The study of discourse often follows the norms set out by Foucault in which the author is critical of a society's standard discourses and tries to get an explicit understanding of that which is problematic in a society by exploring the nuances of discourse. According to Fairclough, the study of discourse usefully studies exceptions and confused cases by referring to inter-textuality (Fairclough, 2000), i.e. to the blending of existing discourses in order to make a new, original, provocative or creative statement. In Western societies discourse often carries simplistic normative dualisms, such as hard work is good and laziness is bad, earning is good and receiving benefits is bad, etc. (Smith, 1998: 343). In the present work, I want to refer to these underlying normative social meanings as the normative undertones which inevitably get carried into development economists' research.

The words 'overtone' and 'undertone' arise in a musical metaphor. Listening to classical music by Haydn or Beethoven -- or to modern pop music with its deep bass accompaniment -- one may notice that whether a note is played in the central octave, one octave up or one octave down helps to determine the emotional impact of the music. Harmonies also knit a piece of music together. The harmonic echoes of any particular note can resonate in the upper and lower reaches of the piano or any other vibrating instrument. The upper tones can offer either shrillness or melody to a piece, while the lower tones tend to offer resonance and a basic 'key' - either a calm major key or a strained minor key. In the same way (though the analogy will soon break down), in economic analysis a neoclassical economist can try to offer clear but simple overtones (such as Pareto optimality) and to avoid undertones of strain that might imply social tension. By contrast a marxist may use both overtones and undertones much more willingly: often offering no clear way forward, with lots of shrill disapproving overtones of complaint, marxists often also use deep undertones of disapproval, negativity, and concern about social stress. Tensions, disagreement about values, and social concerns are much more explicitly embedded in marxist analyses (and to some extent in feminist analyses) than in neoclassical and new institutionalist analyses. One can then imagine holding a debate about the proper approach for a labour economist: Should they or could they avoid using these emotively charged harmonic echoes? I will look at a few examples to begin working on this question.

In Table 2, row 3, selected undertones are listed. Some of these are on a dichotomous register of goodness/badness in modern western society. For instance, for marxists class polarisation has bad undertones as it is assumed to imply class exploitation. For neoclassical economists, market imperfections have bad undertones. Furthermore, bribery has a negative connotation in both these schools. The theft of land would also perhaps have a negative connotation in both schools, whereas land redistribution by the state would be viewed positively by MPE and negatively by NCE. ${ }^{\text {xiv }}$ Among feminists, the undercurrents of disapproval surround phrases that describe exploitation, oppression, females' invisibility, and gender stereotyping. Each school has some undertones or other.

But in addition to these hints at goodness/badness of economically relevant phenomena, there are more complex undertones too. This is the great advantage of doing scientific research on matters of social concern. The economist often concerns her/himself with the paradoxical nature of society. Certain intrinsic dilemmas of 
particular mechanisms that are found to surround social problems are often pointed out. Sayer notes (2000b: 159-167) that 'critical social science' (CSS) is the wideranging set of schools that have focused upon social problems, and it is CSS to which I'm now also referring. To give two examples from Table 2, commerce and other market activity - e.g. earning wages - is usually seen as intrinsically good in the neoclassical discourse, but it is posed as a problem (leading to the dual burden on women) in the feminist discourse. Neoclassical authors are well aware of such paradoxes. Paradoxically, though, wage-earning also creates opportunities for the empowerment of women (Walby, 1997). Feminists disagree among themselves about the positive benefits of women's employment, so the undertones of approval/disapproval become an explicit topic of discussion (Walby, 2001; Harding, 2001). Specifically, as often found in CSS, those who advocate an explicit awareness of women's double exploitation are also assuming that having that awareness would help society's agents to solve the problem of exploitation. Sayer thinks this may be a facile assumption. One's knowledge of falsehood does not necessarily imply that we know of a feasible, acceptable solution to the concrete social problem (2000b: 161). But by having a discussion about the dilemma of transformative knowledge, and taking interest in progressive knowledge in general, feminists have made great contributions to social science epistemology.

If we apply similar logic to formalist political economy, Basu and Van's theorisation of child labour becomes interesting (1998). Basu and Van argue that child labour can occur as one of several simultaneously possible multiple equilibria in a system of equations that represents the employer-employee-family triad of relationships. In Basu's view, sending a child out to do paid work can be optimal but not the only optimal solution to the family labour-supply decision problem (Basu, 2005). Basu has argued, furthermore, that if the government intervenes under these conditions by fining employers a small amount, child labour may actually increase rather than decrease (Basu and Chau, 2003). By making these arguments Basu is very closely allied to New Institutional Economics and to NCE but is making a delicate normative distinction. He seems to argue that it is not his preferences that matter, but the economic agents' preferences that matter. His normative overtones are very lightly expressed indeed. However, at the same time, he recognizes the widespread desire to eradicate the exploitative and damaging forms of child labour (whilst retaining those forms of child labour which are socially acceptable). Basu is attempting a classically value-neutral stance. He offers only true conditional statements arising from formal models. Those applying his model are going to offer empirically grounded deductive statements which assume the model does fit the data.

This form of value-neutrality is a special one which offers an objectivist epistemology without invoking a realist ontology. Basu attempts, then, to make available 'facts about values' without offering any values about his facts. However, the undertones are present in this work. Child labour's generally negative undertones, both in USA and India, are present. Child labour's dilemmatic quality - noted by other authors, such as Satz (2003) on norms, in particular - is highlighted by Basu of course. But the whole rationale for doing the research - a meta-purpose, we might say - is that solving the problem of child labour is a serious social problem which involves using valued, complex moral reasoning. Basu's methods thus contribute to complex moral reasoning yet he doesn't want to adhere to a particular policy position; this is an example of a performative contradiction. ${ }^{x v}$ The person's stance that he is value- 
neutral contradicts his desire, which is evidently a basic assumption he is making, to take actions to change something in society.

Thus in summary, Basu's studies of child labour have attempted to avoid explicit normative overtones but have invoked important, widely recognised normative undertones. By doing so there is a tacit recognition that economic research on labour takes up problems which are ethically contentious. Development economists attempt to generate useful knowledge about the dilemmas as well as about the actions that are involved. .vi

Yet a strong empiricist theme in development economics research (for instance, in Mukherjee et al., 1998: 30-35) argues that the researcher must be neutral between competing viewpoints. Instead of avoiding difficult issues, the economist is seen as commenting on these issues from outside. Sarantakos (1993) illustrates this general viewpoint:

While quantitative researchers adhere to all the principles listed below, qualitative researchers adhere to only a few:

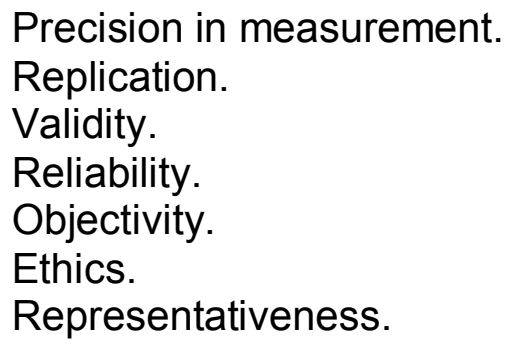

...Objectivity is generally employed to minimise personal prejudice and bias, and to guarantee that social reality will be presented as it is, rather than as it is interpreted or imagined by the investigator. (Sarantakos, 1993: 18-19; italics in original).

Ironically this position creates another performative contradiction. The person advocating neutrality is essentially also taking a position that a researcher should not act as an active agent in the economy. Yet their research is a form of agency. This confusion undermines the arguments of advocates of value-neutrality. It is important to recognise that a lively and unresolved debate has already occurred around this issue (Lacey, 1999; Harding, 1995 and 1999).xvii

An example will help to illustrate a related contradiction of undertones. This example uses statistical data to illustrate the apparent normativity of economic authors. In the development economics research on wage-rates in India, wage regressions have as the dependent variable the log of the wage-rate. The $X$ variates (or independent variables) are seen as co-associated with, and probably caused by, the things that are represented by the independent variables. Studies by Kingdon (1999) and by Knight and Sabot (1982) focus in part on the gender residual in a wage equation. This residual is the coefficient on the sex of the worker and is taken to be a sign of market imperfections (judged bad), or of gender discrimination (also judged bad because of being unfair). Detailed selectivity adjustments are made so that no 'bias' exists in the measurement of the gender residual. Some authors decompose the 
gender pay gap into its 'explained' and 'unexplained' components. The 'gender pay gap' has a negative normative undertone. However, some authors argue that unobserved gender-specific worker heterogeneity causes the apparent gender wage difference, and this heterogeneity has a much less clear connotation (Hakim, 1996). All the wage studies tend to assume that higher wages are good for workers and to suggest that the rewards to education (deemed good) should be equalised across sectors (reflecting fairness, also connotated as a good thing). However the idea that workers who are lazy or who prefer low productivity levels will actually be happy with a lower wage - and that this may be ex post concentrated among women - suggests that there is no negative connotation to the gender wage residual. Furthermore, it has been suggested, women may prefer working at home and having their job close to home, causing them to do less job search and to take jobs for which they are overqualified. This controversy is going to go on and on, and involves two competing normative undertones to the coefficient on 'sex' in wage equations. No wage equation can be presented without these connotations floating around, at least vaguely, in the readers' minds.

The general point is that attempting to be value-neutral creates contradictions. My argument depends more on the presence of normative overtones than on the inevitable presence of normative undertones. The neoclassical economists and positive economists typically assiduously avoid overtones. Their view of undertones would be that they are 'in the eye of the beholder'.

In the view of development economists, the neoclassical and NIE paradigms are very influential (Chang, 2003b). It is worth considering, then, whether having normative undertones alone is sufficient to make development economics an inherently nonvalue-neutral (sic) enterprise. If so, then NCE and NIE must pay more attention to modes of complex moral reasoning - ie they need to provide some new and explicit normative overtones - or else they will be dismissed as neglecting an obvious hole in their logic.

In other words, development economists cannot both have value-neutral research and draw policy conclusions. If they want to draw policy conclusions, it would be wise to have complex and explicit moral reasoning rather than just a series of undertones.

\section{An Example Illustrating Moral Undertones in a Statistical Analysis}

My second example of regression in Indian labour economics is the linear regressions used by Skoufias (1993b) in a neoclassical model of labour use among Indian farmers of three villages over the period 1975-1984. The paper contains three concepts with normative undertones. The body of the paper is offered as valueneutral but at the start and the ending the author gives policy-relevant normative claims, i.e. overtones. I'll describe his model and then the undertones.

The dependent variable was the log of the days of paid labour used (i.e. casual labour demanded by the farm household for that farm). The associated covariates were: \{ male and female wage-rates; bullock wage-rate; area cultivated; other inputs used; whether land was on lease; soil type; rainfall \}. Controls for the year and the village were also used so that both fixed-effects and random-effects models could be 
estimated and compared (Skoufias, 1993b: 27). A second equation was also estimated. This equation examines days of paid labour used in the planting stage of operations as the dependent variable. Male, female and bullock labour are placed into separately estimated equations. The associated covariates were: \{ male, female and bullock wage-rates; area cultivated; other inputs used; whether land was on lease; soil type; rainfall; onset of rain; timing of rain \}(ibid., 28).

The author is mainly trying to test whether the timing and quantity of rain affects the labour purchased, and hence affects the estimates from the first equation. There is strong gender differentiation in the demand for human labour.

The author concludes from equation 1 (whose specification is now accepted through analysing equation 2) that the wage rates on the labour market for casual labour do affect farm households' decisions about both male and female labour. The female labour used is not significantly affected by changes in bullock wages, whereas male labour use is affected by both male wage-rates and by bullock wage-rates. By using time-series data and a complex model, agroclimatic and other factors act as control variables.

Three undertones in this study can be picked out. Firstly, as usual in NCE (see Table 1), more production is considered better than less. Related to this, more efficient production is considered to be better than inefficient production. Therefore, to use less bullock labour when/where bullock time has a higher wage is efficient, and the model is found satisfactory. (This deductive logic so far tends to be verificationist rather than falsificationist in its logic.) Similarly, women's hired labour costs less than two-thirds the price of men's labour. The notion that cheaper women's labour can be substituted for expensive labour is an underlying theme throughout the article. Thus, a discourse which is generally approving of the efficient use of scarce resources is present.

Secondly, we can discern an undertone in the factors indicating input use and agroclimatic conditions. Natural resources are assumed to be present, and the use of nature by the farmer is assumed superior to letting the land lie fallow. Thus, a human-centred world view is displayed. This undertone is not contested in the paper and lies dormant.

Thirdly, the presence of rain and its effect on labour use (and hence on productivity) has an implicitly positive affect undertone. These tropes refer implicitly to a production-centred, 'more is better' ethic. ${ }^{\text {xviii }}$

The paper is generally written in a factual way and contains an introduction, theoretical model, econometric model incorporating farmers' risk aversion, data section, and results. However in the introduction, Skoufias has strong normative overtones. The opening paragraph says:

Labour market participation is the major source of income for many landless and small farm households in rural areas of developing countries. Seasonal fluctuations in wage and employment opportunities of households may thus have serious effects on household income and welfare. . . . Both the design 
and prior evaluation of the effects of . . . policies on rural incomes requires an understanding of the interseasonal determinants of labor demand and supply decisions of rural households. (Skoufias, 1993b: 20).

In this paragraph, the first sentence implies that earning money in the casual labour market is good; the second implies that a lack of earnings can cause seasonal poverty, which is bad; and the third that policy decisions require information about the factors causing higher or lower demand for paid labour in rural areas. However, as a normative stance this is not very coherent. The author puts their empirical research to work at the service of those who design and evaluate policy. A division of labour is in place. Complex moral reasoning is postponed. Instead, mere nuances of overtones are given, and instead undertones are the predominant way of indicating that the author does have a system of values in his work.

My analysis of this exemplar is consistent with the scientific essentialist interpretation of Lloyd (1995). Lloyd argues that the epistemological interpretation of objectivity often summarised as value neutrality - is incoherent. Lloyd and I would both argue that Skoufias' findings are of great interest. The weakness is that the undertones and overtones are not well developed. More could be said about alternative ways that this socio-economic system could develop.

It is a huge challenge to write explicit normative overtones into a piece of research. Those who attempt it will be part of democratic debate on social change. Sen, for instance, does not claim value-neutrality. For example, Dreze and Sen (1995; 2002) engage in well-reasoned complex moral debate. The human capabilities school opens up options for this reasoning which are, as yet, under-developed (Sen, 1993; Nussbaum, 1993). Among development economists, then, an important choice has been opened up: whether to leave the normative overtones to later or whether to grasp normative issues more explicitly.

\section{Summary and Conclusions}

In this paper I explored the normative nuances of five main existing theories of labour relations. I pointed out that the theories often refer to the same things, and that pluralism is structured and constrained by the real nature of these things (such as markets, contracts, employers and workers). I advocated a pluralism that downplays incommensurability and improves the capacity of researchers to bridge between theories.

I introduced the more detailed concepts of normative overtones and normative undertones in order to highlight the inevitable connections between complex moral reasoning, strategies for change, intentionality of the researcher, and social norms. I gave examples from labour research that illustrated the qualitative and norm-ridden nature of such research. I thus argued against a model of the economist as valueneutral. I further argued that performative contradictions exist in the value-neutrality approach. Regression models were used to illustrate these points.

Having shown that norms are frequently present in economic research, I drew out in Table 2 some examples of the affect polarities (good/bad) that are present in some of 
the main discourses about labour relations. The arguments in Table 2 clearly overlap with what leading development economists actually do. Stiglitz, for instance, advocates decent work (Stiglitz, 2002); Sen advocates increasing women's public visibility and challenging women's exploitation in the gender order in India (Drèze and Sen, 2002). The paper goes beyond these authors, however, in making explicit the possibility of pluralism and the strong need for a qualitative grounding of survey research on labour issues. Academics have to make their surveys interact with lay discourses so that survey questions are strategically targeted to have the maximum good effect in the long run.

A term used by Sayer to refer to the complex iteration of academic and lay normativities, taking into account both the economic and the social/cultural axes, is 'ethical naturalism' (Sayer, 2005: 21). Ethical naturalism refers to the real existence of injury and well-being in human lives and in society. Sayer argues against seeing well-being purely in social constructivist terms. He would suggest that the reality of injury causes academic authors to bring suffering to the light. There will be dynamics and iterative learning in the process of conducting and writing up research. The innate empathy or compassion of an author is inevitably going to cause them to focus on certain human problems and concerns (this innate tendency is described by Wilkinson as a fascination with the senselessness of suffering, Wilkinson, 2005). An author's own suffering - past or present - may cause them to choose particular topics, as hinted by Sen (1980).

Sayer also argues against seeing change purely in rational terms. The competing strategies actually found in the labour literature are profoundly differentiated. Pareto optimality creeps in from the neoclassical tradition, with all its irrealist foundations in mathematical modelling. Instead of Pareto-optimality based subjectivism, it is useful for development economists to develop a more realist notion of ethics. Realist ethics have come to be known as Aristotelianism or similar (Flyvberg, 2001, Nussbaum, 1996). That way, bad outcomes can be labelled as bad. In this framework, an economist is likely to recognise their own role as a change-agent whilst being very humble about their very limited capacity (individually) to change things for the better. This places the economist as a rational person working in an open system composed of the academic sphere interlinked with other social domains and systems such as the class system and gender order.

By contrast, among marxists, the urge to compress an income distribution may arise but is not necessarily practical or realistic, given the profoundly entrenched bases of class power. What emerges then is necessarily a complex normative scene. Perhaps the paper has opened up an area of new research in which coherency, transformativeness, and progressiveness of proposals for change can be compared and contrasted across schools of thought. The child labour debate illustrated the subtle role of connotations in the use and development of theory. In other words theoretical pluralism (Table 1) leads toward an interest in competing moral approaches (Table 2). The traditional epistemic tenets listed by Sarantakos need to be amended to include the substantive moral dimension. 


\section{References}

Agarwal, B. (2003). "Gender and Land Rights Revisited: Exploring New Prospects via the State, Family and Market." Journal of Agrarian Change 3(1 and 2): 184-224.

Agarwal, B. (2003). "Women's Land Rights and the Trap of Neo-Conservatism: A Response to Jackson." Journal of Agrarian Change 3(4): 571-585.

Athreya, B. V., G. Djurfeldt, and S. Lindberg. (1990). Barriers Broken: Production Relations and Agrarian Change in Tamil Nadu. New Delhi, Sage.

Bardhan, P. (2005). "Theory or Empirics in Development Economics." Economic and Political Weekly XL(40): 4333-4335.

Basu, A. K. and N. H. Chau (2003). "Targeting Child Labor in Debt Bondage: Evidence, Theory, and Policy Implications." The World Bank Economic Review 17(2): 255.

Basu, K. (2005), 'Child Labor and the Law: Notes on Possible Pathologies,' Economics Letters, vol. 87, 169-174.

Basu, K. (2005). "New Empirical Development Economics: Remarks on Its Philosophical Foundations." Economic and Political Weekly XL(40): 4336-4339.

Basu, K. 1984. "Implicit Interest Rates, Usury and Isolation in Backward Agriculture." Cambridge Journal of Economics 8: 145-159.

Basu, K. and P. H. Van (1999). "The economics of child labor: Reply." The American Economic Review 89(5): 1386.

Basu, K. and Z. Tzannatos (2003). "The Global Child Labor Problem: What Do We Know and What Can We Do?" The World Bank Economic Review 17(2): 147.

Beneria, L. (1979). "Reproduction, production and the sexual division of labour." Cambridge Journal of Economics 3: 203-225.

Beneria, L. (2003). Gender, development, and globalization: economics as if all people mattered. New York; London, Routledge.

Bhaduri, A. (1983a). "Cropsharing as a Labour Process." Journal of Peasant Studies 10(2-3): $88-93$.

Bhaduri, A. (1983b). The Economic Structure of Backward Agriculture. London, Academic Press.

Bhaduri, A. (1986). "Forced Commerce and Agrarian Growth." World Development 14(2): 267-272.

Bhowmik, S. and R. Jhabvala (1996). Rural Women Manage their Own Producer Cooperatives: Self-Employed Women's Association (SEWA) / Banaskantha Women's Association in Western India. Speaking Out: Women's Economic Empowerment in South Asia. M. Carr, M. Chen and R. Jhabvala. London, IT Publications, Aga Khan Foundation and UNIFEM: 105-125.

Braverman, A., and R. Kanbur, (1987), 'Urban Bias and the Political Economy of Agricultural Reform.' World Development, Vol15, No.9, pp.1179-87.

Cammack, P. (2002) "Neoliberalism, The World Bank, and the New Politics of Development", Ch. 9 in Kothari and Minogue, 2002.

Carter, B., and Caroline New, Ed. (2004). Making Realism Work: Realist Social Theory and Empirical Research. London, Routledge.

Chakravarti, U. (1993). "Conceptualizing Brahmanical Patriarchy in Early India - Gender, Caste, Class and State." Economic and Political Weekly 28(14): 579-585.

Chang, H.-J. (2003a). The Market, the State and Institutions, chapter 2 in Economic Development. Rethinking Development Economics. H.-J. Chang. London, Anthem Press.

Chang, H.-J., ed. (2003b). Rethinking Development Economics. London, Anthem Press.

Danermark, B. (2001). Explaining society: an introduction to critical realism in the social sciences. London, New York, Routledge.

Dow, S. (2002). Economic Methodology: An Enquiry. Oxford and New York, Oxford University Press. 
Dow, S. (2004) Structured Pluralism, Journal of Economic Methodology, 7:3.

Dowd, D. (2000). Capitalism and its Economics: A Critical History. London, Pluto.

Dreze, J. and A. K. Sen (1995). India: Economic Development and Social Opportunity. Oxford, Clarendon Press.

Dreze, J. and A. K. Sen (2002). India: development and participation. Oxford, Oxford University Press.

Dube, L. (1988). "On the Construction of Gender - Hindu Girls in Patrilineal India." Economic and Political Weekly 23(18): WS11-WS19.

Ekstrom, M. (1992). "Causal Explanation Of Social-Action - The Contribution Of Weber,Max And Of Critical Realism To A Generative View Of Causal Explanation In SocialScience." Acta Sociologica 35(2): 107-122.

Ellis, F. (1993). Peasant economics: farm households and agrarian development. Cambridge, England, Cambridge University Press.

Elson, D. (1996). Male bias in the development process. Manchester, Manchester University Press.

Epstein, T. S., A. P. Suryanarayana, et al. (1998). Village Voices: Forty Years of Rural Transformation in South India. New Delhi, Thousand Oaks and London, Sage.

Fairclough, N. (2001). Language and power: second edition. Harlow, England, Longman.

Fairclough, N. (2003). Analyzing discourse: textual analysis for social research. London and New York, Routledge.

Flyvbjerg, B. (2001). Making social science matter: why social inquiry fails and how it can succeed again. Cambridge, Cambridge University Press.

Garnett, R. F. (1999). What do economists know? new economics of knowledge. London; New York, Routledge.

Gasper, D. (2004). The ethics of development: from economism to human development. Edinburgh, Edinburgh University Press.

Grillo, R. D. and R. L. Stirrat (1996). Discourses of development: anthropological perspectives. Oxford \& NY, Berg.

Hands, D. W. (2001). Reflection without rules: economic methodology and contemporary science theory. Cambridge, Cambridge University Press.

Harding, S. (1995). "Can Feminist Thought Make Economics More Objective." Feminist Economics 1:1: 7-32.

Harding, S. (1999). "The case for strategic realism: A response to Lawson." Feminist Economics 5(3): 127-133.

Harding, S. (2001). "Comment on Walby's "Against epistemological chasms: The science question in feminism revisited": Can democratic values and interests ever play a rationally justifiable role in the evaluation of scientific work'?" Signs 26(2): 511-525.

Harriss-White, B. (2003). India Working: Essays on Society and Economy, Cambridge: Cambridge University Press.

Harriss-White, B. and E. Janakarajan (2004). Rural India facing the 21st century. London, Anthem Press.

Hodgson, G. (2000). "What is the Essence of Institutional Economics?" Journal of Economic Issues 34(2): 317-329.

Hodgson, G. M. (2004). The Evolution of Institutional Economics: Agency, Structure and Darwinism in American Institutionalism. London, Routledge.

Hoff, K. and J. E. Stiglitz (1998). "Moneylenders and bankers: price-increasing subsides in a monopolistically competitive market (vol 52, pg 429, 1997)." Journal of Development Economics 55(2).

Hunt, D. (1989). Economic theories of development: an analysis of competing paradigms. Hemel Hempstead, Harvester Wheatsheaf.

Hutchinson, F., M. Mellor, and W.K. Olsen. (2002). The politics of money: towards sustainability and economic democracy. London, Pluto Press.

Jackson, C. (2003). "Gender Analysis of Land: Beyond Land Rights for Women?" Journal of Agrarian Change 2003(3): 4. 
Joseph, C. and K. V. E. Prasad (1995). Women, work and inequity: the reality of gender. New Delhi, New Labour Institute.

Kabeer, N. (2000). The Power to Choose: Bangladeshi Women and Labor Market Decisions in London and Dhaka. London.

Kabeer, N. (1994). Reversing Reality. London, Sage.

Kanth, chapter in Fleetwood, S., Ed. (1999). Critical Realism in Economics: Development and Debate. London and NY, Routledge.

Kapadia, K. (1996). Discipline and Control: Labour Contracts and Female Labour. Meanings of Agriculture: Essays in S. Asian History and Economics. P. G. Robb. Oxford, Oxford Univ. Press: 262-284.

Kapadia, K. (1999). "Gender ideologies and the formation of rural industrial classes in South India today." Contributions to Indian Sociology 33(1-2): 329-352.

Kingdon, G. G. (1999) "Labour force participation, returns to education and sexdiscrimination." Gender and Employment in India: 249-277. In Papola, T. S., A. N. Sharma, et al. (1999). Gender and employment in India. New Delhi, Vikas Pub. House.

Knight, J. B. and R. H. Sabot (1982). "Labor Market Discrimination in a Poor Urban Economy." The Journal of Development Studies 19(1): 67-87.

Kothari, U., and M. Minogue (2002). Development Theory and Practice: Critical Perspectives, London: Palgrave.

Lacey, H. (1999). Is Science Value Free? Values and Scientific Understanding. London \& New York, Routledge.

Lawson, T. (1997). Economics and reality. London; New York: Routledge.

Layder, D. (1998). The Reality of Social Domains: Implications for Theory. Knowing the Social World. T. May, and Malcolm Williams. Buckingham and Philadelphia, Open University Press: 86-102.

Lipsey, R. G. (1989). An Introduction to Positive Economics. London, Weidenfeld and Nicolson.

Lloyd, E. A. (1995). "Objectivity and the double standard for feminist epistemologies." Synthese 104(3): 351.

MacIntyre, A. (1985 (orig. 1981)). After Virtue: A Study in Moral Theory. London, Duckworth Publishers.

Maclntyre, A. (1990). Three Rival Versions of Moral Enquiry. Notre Dame, Indiana, Notre Dame Press.

Majumdar, M. (2001). "Child Labour as a Human Security Problem: Evidence From India." Oxford Development Studies 29(3).

Mathur, A. (1994). "Work Participation, Gender and Economic Development: A Quantitative Anatomy of the Indian Scenario." The Journal of Development Studies 30(2): 466504.

May, T., and Malcolm Williams, Eds. (1998). Knowing the Social World. Buckingham and Philadelphia, Open University Press.

Mayoux, L. (1993). "A Development Success Story - Low Caste Entrepreneurship and Inequality - an Indian Case-Study." Development and Change 24(3): 541-568.

Mikkelsen, B. (1995). Methods for Development Work and Research. London, Delhi and Thousand Oaks, Sage.

Mookherjee, D. (2005). "Is There Too Little Theory in Development Economics Today?" Economic and Political Weekly XL(40): 4328-4333.

Mukherjee, C., H. White, and M. Wuyts. (1998). Econometrics and data analysis for developing countries. London; New York, Routledge.

New, C. (1996). Agency, Health and Social Survival. London, Taylor and Francis.

Nussbaum, M. (1993). Non-Relative Virtues: An Aristotelian Approach. The Quality of Life. M. Nussbaum and A. K. Sen. Oxford, World Institute for Development Economics Research (WIDER) of the UN University, and Clarendon Press: 242-269.

Nussbaum, M. (1999). "Women and equality: the capabilities approach." International Labour Review 138(3). 
Nussbaum, M. (2004) Hiding From Humanity: Disgust, Shame, and the Law, Princeton: Princeton University Press.

Olsen, W. K. (1996). Rural Indian Social Relations. Delhi, Oxford University Press.

Olsen, W.K. (2005), Moral Political Economy and Poverty: Four Theoretical Schools Compared, Global Poverty Research Group, Working Paper No. 31, www.gprg.org.

Olsen, W.K. (2006a). Pluralism, Poverty and Sharecropping: Cultivating Open-Mindedness in Journal of Development Studies, 42:7, pgs. 1130-1157.

Olsen, W.K. and S. Mehta, (2006) A Pluralist Account of Labour Participation in India, Global Poverty Research Group, Working Paper No. 42, www.gprg.org.

Olsen, W.K., and J. Morgan (2005) A critical epistemology of analytical statistics: Addressing the sceptical realist, Journal of the Theory of Social Behaviour, 35:3, September, pages 255-284.

Olsen, Wendy (2006b) "Moral Political Economy and Poverty: Four Theoretical Schools Compared", submitted to Cambridge Journal of Economics, Oct.; under revision; working paper of GPRG.

O'Neill, J. (1998). The Market: Ethics, Knowledge and Politics. London, Routledge.

Papola, T. S., A. N. Sharma, et al. (1999). Gender and employment in India. New Delhi, Vikas Pub. House.

Patomaki, H. (2006). "Realist Ontology For Futures Studies." Journal of Critical Realism 5(1): $1-31$.

Pieterse, J. N. (2001). Development Theory: Deconstructions/Reconstructions. London, Sage.

Quine, W.V.O. (1953), 'Two Dogmas of Empiricism' in W.V.O. Quine, From a Logical Point of View, Boston, Massachusetts: Harvard University Press.

Ramachandran, V. K. (1990). Wage Labour and Unfreedom in Agriculture: An Indian Case Study. Oxford, Clarendon Press.

Ramani Rao, S. V., S. Ghosh, et al. (1994). Women at Work in India, Vol. 2: An Annotated Bibliography. Delhi, Sage.

Rogaly, B. (1997). "Embedded Markets: Hired Labour Arrangements in West Bengal Agriculture." Oxford Development Studies 25(1): 209-223.

Rogaly, B. (1997). "Embedded Markets: Hired Labour Arrangements in West Bengal Agriculture." Oxford Development Studies 25(1): 209-223.

Rogaly, B., B. Harriss-White, et al. (1999). Sonar Bangla? agricultural growth and agrarian change in West Bengal and Bangladesh. New Delhi; London, Sage Publications.

Rogaly, B., D. Coppard, et al. (2003). "Seasonal migration, employer-worker interactions, and shifting ethnic identities in contemporary West Bengal." Contributions to Indian Sociology 37(1-2): 281-310.

Roth, P.A. (1987), Meaning and Method in the Social Sciences: A Case for Methodological Pluralism, Ithaca and London: Cornell University Press.

Sarantakos, S. (1993). Social research. Basingstoke, Macmillan.

Satz, D. (2003). "Child Labor: A Normative Perspective." The World Bank Economic Review 17(2): 297.

Sayer, A. (1992 (orig. 1984)). Method in Social Science: A Realist Approach. London, Routledge.

Sayer, A. (2005). The Moral Significance of Class. Cambridge, Cambridge University Press.

Sayer, A. (2000b). Moral Economy and Political Economy. Studies in Political Economy, Spring, 79-103.

Sayer, Andrew (2000a). Realism and Social Science. London: Sage.

Sen, A. K. (1980). "Description as Choice." Oxford Economic Papers 32.

Sen, A. K. (1993). Capability and Well-Being. The Quality of Life. M. Nussbaum and A. K. Sen. Oxford, World Institute for Development Economics Research (WIDER) of the UN University, and Clarendon Press: 30-53.

Singh, M. (1995). Uneven Development in Agriculture and Labour Migration: A Case of Bihar and Punjab. Shimla, Indian Institute of Advanced Study. 
Skoufias, E. (1993a) 'Labour Market Opportunities and Intrafamily Time Allocation in Rural Households in South Asia", Journal of Development Economics, 40, 277-310.

Skoufias, E. (1993b). "Seasonal Labor Utilization in Agriculture - Theory and Evidence from Agrarian Households in India." American Journal of Agricultural Economics 75(1): 20 32.

Skoufias, E. (1995). "Household Resources, Transaction Costs, and Adjustment through Land Tenancy." Land Economics 71(1): 42-56.

Smith, M.J. (1998) Social Science in Question, London: Sage, in association with the Open University Press.

Smith, Stephen W. (1994) Labour Economics, London: Routledge.

Srinivasan, T.N. (1989), 'On Choice Among Creditors and Bonded Labour Contracts' in P.K. Bardhan (ed.), The Economic Theory of Agrarian Institutions, Oxford: Clarendon Press (pp.203-20).

Stiglitz (2002). "Employment, Social Justice, and Societal Well-Being." International Labour Review 141(1-2): 9-29.

Stiglitz, J. E. (2003 (orig. 2002)). Globalisation and Its Discontents. London, Penguin (original Allen Lane 2002).

Todaro, M. P. (1997). Economic development. London, Longman c1997.

Vohra, G. (1990) Altering Structures: Innovative Experiments at the Grassroots, Delhi: Tata Institute.

Walby, S. (1997). Gender transformations. London; New York, Routledge.

Walby, S. (2001). "Against Epistemological Chasms: The Science Question in Feminism Revisited." Signs 26(2): 485-509.

Wilkinson, I. (2005). Suffering: A Sociological Introduction. London, Polity.

Williams, M. (2005). "Situated Objectivity." Journal for the Theory of Social Behaviour 35(1): 99-120.

Wolfe, A. (2001). Moral freedom: the impossible idea that defines the way we live now. New York; London, W.W. Norton. 
Table 1: Five Schools Of Thought On The Economics Of Labour Relations In India

\begin{tabular}{|c|c|c|c|c|c|}
\hline & $\begin{array}{l}\text { Neoclassical } \\
\text { Economics }\end{array}$ & $\begin{array}{l}\text { New } \\
\text { Institutionalist }\end{array}$ & $\begin{array}{l}\text { Marxist } \\
\text { Political } \\
\text { Economy }\end{array}$ & $\begin{array}{l}\text { Formalised } \\
\text { Political } \\
\text { Economy }\end{array}$ & $\begin{array}{l}\text { Gender and } \\
\text { Development } \\
\text { (Feminist) }\end{array}$ \\
\hline $\begin{array}{l}\text { Objects of } \\
\text { theory (the } \\
\text { ontic content) }\end{array}$ & $\begin{array}{l}\text { Workers, firms, } \\
\text { employers, } \\
\text { human capital, } \\
\text { markets, } \\
\text { demand for } \\
\text { labour, supply } \\
\text { of labour }\end{array}$ & $\begin{array}{l}\text { Workers and } \\
\text { employers as } \\
\text { principal and } \\
\text { agent; contracts; } \\
\text { markets; } \\
\text { decisions; } \\
\text { information }\end{array}$ & $\begin{array}{l}\text { Social classes, } \\
\text { interacting with } \\
\text { castes and } \\
\text { state } \\
\text { government }\end{array}$ & $\begin{array}{l}\text { Idealised } \\
\text { actors }\end{array}$ & $\begin{array}{l}\text { Various types } \\
\text { of agent who } \\
\text { reflexively } \\
\text { contemplate } \\
\text { the actions } \\
\text { they take and } \\
\text { their effects; } \\
\text { men, women, } \\
\text { the state, } \\
\text { traditions, } \\
\text { customs, } \\
\text { norms }\end{array}$ \\
\hline $\begin{array}{l}\text { Ontic } \\
\text { assumptions }\end{array}$ & $\begin{array}{l}\text { Individualistic } \\
\text { optimising } \\
\text { predominates; } \\
\text { labour market } \\
\text { demand and } \\
\text { supply are } \\
\text { known and they } \\
\text { create a context } \\
\text { of free choices }\end{array}$ & $\begin{array}{l}\text { Modelling iconic } \\
\text { agents gives } \\
\text { worthwhile } \\
\text { predictions; utility } \\
\text { is } \\
\text { mathematizable; } \\
\text { situated optimising } \\
\text { occurs; markets } \\
\text { are not } \\
\text { competitive } \\
\text { because } \\
\text { information is not } \\
\text { free }\end{array}$ & $\begin{array}{l}\text { Structures } \\
\text { interact with } \\
\text { each other; } \\
\text { agents in social } \\
\text { relations do not } \\
\text { simply make } \\
\text { free choices; } \\
\text { people act } \\
\text { according to } \\
\text { their class } \\
\text { interest }\end{array}$ & $\begin{array}{l}\text { Idealised } \\
\text { actors } \\
\text { interact in a } \\
\text { simplified } \\
\text { hypothetical } \\
\text { world with } \\
\text { assets, } \\
\text { resources } \\
\text { and } \\
\text { preference } \\
\text { sets given in } \\
\text { advance of } \\
\text { interaction }\end{array}$ & $\begin{array}{l}\text { Society has } \\
\text { interwoven } \\
\text { layers (a depth } \\
\text { ontology; } \\
\text { Layder, 1998); } \\
\text { stereotypes } \\
\text { and norms } \\
\text { exist; agents } \\
\text { are important } \\
\text { actors in } \\
\text { construing } \\
\text { social } \\
\text { relations, }\end{array}$ \\
\hline Examples: & $\begin{array}{l}\text { Knight and } \\
\text { Sabot, 1982; } \\
\text { Skoufias, } \\
\text { 1993a }\end{array}$ & $\begin{array}{l}\text { Skoufias, 1993b; } \\
\text { Srinivasan, } 1989\end{array}$ & $\begin{array}{l}\text { Ramachandran, } \\
\text { 1990; Singh, } \\
1995\end{array}$ & $\begin{array}{l}\text { Basu and } \\
\text { Van, 1998; } \\
\text { Basu, 2005 }\end{array}$ & $\begin{array}{l}\text { Kapadia, } \\
\text { 1996; 1999; }\end{array}$ \\
\hline
\end{tabular}

Note: See also Olsen (2006a). 
Table 2: Selected Normative Connotations of Economic Theories of Labour Relations

\begin{tabular}{|c|c|c|c|c|c|}
\hline & $\begin{array}{l}\text { Neoclassical } \\
\text { Economics }\end{array}$ & $\begin{array}{l}\text { New } \\
\text { Institutionalist }\end{array}$ & $\begin{array}{l}\text { Marxist } \\
\text { Political } \\
\text { Economy }\end{array}$ & $\begin{array}{l}\text { Formalised } \\
\text { Political } \\
\text { Economy }\end{array}$ & $\begin{array}{l}\text { Gender and } \\
\text { Development } \\
\text { (Feminist) }\end{array}$ \\
\hline $\begin{array}{l}\text { Overtones: } \\
\text { Explicit or } \\
\text { Implicit Over- } \\
\text { arching } \\
\text { Normative } \\
\text { Reasoning }\end{array}$ & $\begin{array}{l}\text { More income } \\
\text { is better; } \\
\text { Pareto } \\
\text { Optimal } \\
\text { changes are } \\
\text { good; efficient } \\
\text { production is } \\
\text { good }\end{array}$ & $\begin{array}{l}\text { Non-market } \\
\text { production will } \\
\text { tend to be less } \\
\text { efficient than } \\
\text { marketised } \\
\text { production }\end{array}$ & $\begin{array}{l}\text { Structures of } \\
\text { oppression } \\
\text { need to be } \\
\text { changed; } \\
\text { changing } \\
\text { them } \\
\text { requires } \\
\text { innovative } \\
\text { discourses of } \\
\text { resistance }\end{array}$ & $\begin{array}{l}\text { Ethical } \\
\text { judgements } \\
\text { are usually } \\
\text { left to the } \\
\text { reader }\end{array}$ & $\begin{array}{l}\text { Women suffer } \\
\text { from both class } \\
\text { and gender } \\
\text { oppression; in } \\
\text { India, caste } \\
\text { structures create } \\
\text { (bad) pressure } \\
\text { on Hindu women } \\
\text { by privatising } \\
\text { their lives and } \\
\text { priorities }\end{array}$ \\
\hline $\begin{array}{l}\text { Concepts } \\
\text { Used to } \\
\text { Denote } \\
\text { Important } \\
\text { Things in the } \\
\text { Theory }\end{array}$ & $\begin{array}{l}\text { Markets, } \\
\text { choice, } \\
\text { returns, } \\
\text { rewards, } \\
\text { investments }\end{array}$ & $\begin{array}{l}\text { information, } \\
\text { asymmetries, } \\
\text { free riders, } \\
\text { market } \\
\text { imperfections, } \\
\text { moral hazard }\end{array}$ & $\begin{array}{l}\text { Class, } \\
\text { oppressive } \\
\text { social } \\
\text { practices, } \\
\text { exploitation, } \\
\text { suffering, } \\
\text { power, } \\
\text { struggle }\end{array}$ & $\begin{array}{l}\text { Power, } \\
\text { choice, } \\
\text { resources, } \\
\text { labour force } \\
\text { participation, } \\
\text { child labour }\end{array}$ & $\begin{array}{l}\text { The gender } \\
\text { order, structures, } \\
\text { stereotypes, } \\
\text { privatised roles, } \\
\text { conformity }\end{array}$ \\
\hline $\begin{array}{l}\text { Examples of } \\
\text { Undertones } \\
\text { Associated } \\
\text { with Certain } \\
\text { Main } \\
\text { Concepts }\end{array}$ & $\begin{array}{l}\text { Goodness of } \\
\text { competitive } \\
\text { market } \\
\text { outcomes; } \\
\text { subjective } \\
\text { goodness of } \\
\text { market } \\
\text { rewards such } \\
\text { as wages }\end{array}$ & $\begin{array}{l}\text { Badness of } \\
\text { market } \\
\text { imperfections; } \\
\text { problematic } \\
\text { nature of moral } \\
\text { hazard resulting } \\
\text { from individual } \\
\text { rational action }\end{array}$ & $\begin{array}{l}\text { Badness of } \\
\text { class-based } \\
\text { exploitation; } \\
\text { intrinsic } \\
\text { value of } \\
\text { seeing } \\
\text { structures as } \\
\text { wholes } \\
\text { (holism) }\end{array}$ & $\begin{array}{l}\text { Badness of } \\
\text { context- } \\
\text { specific ills } \\
\text { such as child } \\
\text { labour. } \\
\text { Argues that } \\
\text { paid work is } \\
\text { often bad for } \\
\text { children. }\end{array}$ & $\begin{array}{l}\text { Injurious effects } \\
\text { of gendered } \\
\text { oppression; } \\
\text { inherent } \\
\text { goodness of } \\
\text { empowerment; } \\
\text { dangers of } \\
\text { stereotypes that } \\
\text { normalise } \\
\text { oppressive } \\
\text { social } \\
\text { relationships as } \\
\text { private desires }\end{array}$ \\
\hline
\end{tabular}

Note: 'Overtones' refers to the over-arching normative framework of proposals that overlies the explanatory claims of a strand of literature. 'Undertones' refers to the underlying meanings and especially to the normative connotations that are associated with the building blocks of a particular discourse. 


\section{Notes}

${ }^{i}$ Moral realism is the view that the good is real. It suggests that the good has an objective or material form. A closely related concept, 'ethical naturalism', is used by philosophers to refer to the person-independent nature of the good aspects of the world in a more refined way. Both phrases offer alternatives to relativism and strong constructivism. See Sayer (2000).

ii Hands' point is that evolutionary epistemologies are found during the move away from positivism. However, there is still very little reference to values in Hands' treatment of the new epistemological developments. Similarly, in Garnett's (edited) volume dated 1999 constructivism enters the scene several times but values are mentioned only thrice (1999: $233,237,239)$. These interesting mentions refer to just the kind of moral reasoning that I wish to examine - human rights discourses, lay discourses, and other approaches which are welfarist and not subjectivist; see Olsen, 2006b.

iii Hands defines critical rationalism as the self-conscious comparison of theories which was advocated in the late writings of Popper, whilst falsification is a separable technique that is more embedded in the early to middle writings of Popper.

iv This boat metaphor is associated with Neurath, and is very similar to the original metaphor of a box or cube used by Quine (1953; see Hands, 2001: 78). The difference, however, is that Quine's metaphor refers to knowledge as touching only superficially on reality, whereas Neurath's boat metaphor can be read to suggest that our knowledge touches on the core of reality, i.e. the boat's workings. In my previous work the metaphor of the boat is used to convey the idea that relations of unequal social class may actually mask reality (Hutchinson, Mellor and Olsen, 2002). The boat's crew are unwilling to challenge the dominant theories conveyed by the boat's captain. In our metaphor, it is possible for false theories to be widely accepted. More importantly, competing theories about the world are forced into commensurability.

${ }^{v}$ An institution can also be seen as a social structure. Each institution has component parts which are in ongoing relation to each other. But, like other structures, the whole has an existence which is greater than the sum of the component parts.

${ }^{v i}$ The first four schools of Table 1 were already described in Olsen, 2006a. The fifth school is described in Olsen (2006b). For this reason, a long description of these schools is omitted here. Development economics, as illustrated here by the Indian case, is rather different from the standard labour economics of Smith (1994). I am selecting the four schools most widely used in contemporary Indian labour economics. Works which illustrate the neoclassical economic school (NCE) include Mukherjee, et al. (1998), Todaro (1997), Knight and Sabot (1982), and Skoufias (1993a). The new institutionalist school (NIE) is illustrated by Skoufias, 1995; Skoufias, 1993; and Srinivasan, 1989. India-based Marxist political economy (MPE) writers include Ramachandran, 1990; Singh, 1995; Athreya et al., 1990; Harriss-White, 2003; and formalised political economy is closely associated with $\mathrm{K}$. Basu and others (FPE); see Basu, 2005. Finally, feminist approaches are reviewed by Beneria, 2003, and by Kabeer, 1994, with examples including Kabeer, 2000 and Kapadia, 1996, 1999.

vii The most important schools omitted here are interpretive economics and old institutionalism. These are not often seen much yet among development economists studying India. Exceptions include the interpretive work of Kapadia and the institutionalism of Harriss-White.

viii Please note that I am not simply 'defining' these undertones and overtones. Instead I am abstracting from the very complex moral reasoning that each development economist does. My abstraction is tending in these two directions - the overtones being the overview statements of normative comparison, and the undertones being the underlying, pre-existing, socially created and given normative meanings that attach to particular words and concepts that are used in research. For a review of the use of abstraction in social theory, see Sayer (1992); and see also Hodgson (2004: 427), where O. North's references to organizations as players is critiqued. Hodgson argues that this is a proper abstraction (in a particular context), but that it should not and does not act to define organisations as players. 
${ }^{\text {ix }}$ Exceptionally, in recent years institutionalist economics has taken a turn toward multidisciplinarity and a political economy of regulation. Excellent works of this kind which are broadly relevant, but not treated here, include Chang (2003), Stiglitz (2002), Braverman and Kanbur (1987), and Hodgson (2004).

${ }^{x}$ For instance, utility functions are not necessarily going to be consistent or coherent. "The notion of individual agents as utility-maximising is regarded as inadequate or erroneous. [Old] institutionalism does not take the individual as given. Individuals are affected by their institutional and cultural situation.' Hodgson, 2000: 318.

xi Furthermore, feminists have made contributions to the methodology debate. Harding argues convincingly against weak value-neutrality and in favour of what she terms 'strong objectivity'. Harding's strong objectivity refers to a realist position in which the agents of change include economists. This view sees the researcher as an agent and asks the reflexive researcher to offer public and explicit rationales for what they are doing and why they recommend particular theories, methods and policy solutions.

xii A more detailed definition is provided by Smith (1998: 343): 'Discourse(s) are systems of representation involving rules of conduct which regulate the production of meaning within the context of definite textual and institutional conditions - they regulate what can and cannot be said and read within historically and socially specific situations.'

xiii The use of the term embedded is deliberate here. The meanings are embedded in the discourse before a person learns and decides to use that discourse. Furthermore the meanings only attach to a phrase in the context where they are both intended, and recognised, to hold those meanings. Thus the context is very important to the nuances. In this embedded context, even if the speaker does not intend to convey a connotation, the connotation that is considered usual can still be conveyed.

xiv It is important to recognise that in India, land reform and land redistribution policies are continually and actively being developed. These policies affect the huge rural labour market as much as, or more than, other labour policies such as minimum wages (generally flouted) and the ban on bonded labour (widely ignored).

$x v$ A performative contradiction arises when the propositional content of a statement contradicts the noncontingent presuppositions that make possible the performance of the speech act, such as occurs with "all statements must be false." - Wikipedia, online source.

xvi It is interesting that Basu hasn't yet studied the beliefs of children about child labour. Among feminists, because of the importance of recognising differences of beliefs about the goodness of actions, there is often a strong commitment to listening to the subjects of research. Thus children, mothers and fathers would be a good subject for new empirical research in the Indian context where new forms of child labour have been banned in 2006. 13 million children are expected to be affected by these new regulations (Majumdar, 2001: 287).

xvii In technical language, I am taking the position that epistemological objectivity is not possible. See Lloyd, 1995.

xviii Readers may not have the patience to plow through such obvious statements. However, there is a justification. In recent years many parts of upland central and southern India have suffered from severe water shortage due to groundwater depletion. There has been rapid growth of water use, and arguably excessive pumping of water out of borewells and open wells. In addition, salination and deterioration of coastal groundwater resources has been a rapid and worrying feature of peri-urban and lowland agriculture. Evidence about these trends makes economists worry that an assumption of costless water -- even from rain -- is causing an unintended ruin in many parts of the Indian countryside. See Harriss-White and Janakarajan (2004) for details. 